\title{
COUNTRY BRAND-STRENGTH INDEX FOR G7 COUNTRIES AND TURKEY
}

\author{
ÍNDICE DE FUERZA DE MARCA PAÍS PARA LOS PAÍSES DEL G7 Y TURQUÍA
}

\author{
Kübra Ulutaş ${ }^{\mathrm{a}}$ \\ Classification: Empirical paper - research \\ Received: June 6, 2020 / Revised: September 29, 2020; February 16, 2020 / Accepted: March 19, 2021
}

\begin{abstract}
Even though, in the past, competition depended on the factors of production possessed, today it depends on the production of value-added goods, their export, and finally, branding of the country today. Since the late 1990s, the brand value of countries has been an important concept that has been studied. Current academic literature is deprived of weighting sub dimensions of country brand strength index and compare index values by years. Having an important role in academic literature, Fetscherin (2010) identified five dimensions of the country brand strength index as export, tourism, foreign direct investment, migration and governance, but not giving any weighting to sub dimensions. In order to contribute to current country brand index literature, sub-dimensions of the index are weighted with the help of the analytical hierarchy process (AHP) method, comparing 2010 and 2015. Therefore, the innovation of this paper is its weighting method and the comparison of index values by years. The Country Brand Strength Index (CBSI) is calculated for G7 countries and Turkey using the survey based AHP method, consisting of 5 different indicators: exports, foreign direct investments, tourism, immigration, and governance. According to the results, it is determined that "exports" has the most important weight among those indicators with Canada leading the group with the best index value in 2010 and 2015. The aim of this study, which was conducted with limited resources, is to shed light on studies to be carried out in the future in order to establish a strong country brand and increase country competitiveness in the international markets. In this respect, repetition of this research as regards to geographical and regional variations and performing qualitative and quantitative studies, incorporating different dimensions in the index such as culture, science and technology, will strengthen the academic literature in this field.
\end{abstract}

Keywords: Brand value, country brand strength index, AHP method.

\section{Resumen}

Mientras que en el pasado la competencia fue por los factores de producción que poseía, hoy día depende de la producción de bienes de valor añadido, su exportación y finalmente el branding del país hoy. Desde finales del año 1990, el valor de marca de los países ha sido un concepto importante que comenzó a estudiarse. La literatura académica actual se priva de ponderar las subdimensiones del índice de fortaleza de la marca del país y comparar los valores del índice por años. Con un papel importante en la literatura académica, Fetscherin (2010) identificó cinco dimensiones del índice de fortaleza de la marca del país como la exportación, el turismo, la inversión extranjera directa, la migración y la gobernanza, pero ya sin dar ninguna ponderación a las subdimensiones. Con el fin de contribuir a la literatura actual del índice de marca del país, las subdimensiones del índice se ponderan con la ayuda del método de proceso jerárquico analítico (AHP) en comparación con 2010 y 2015. De esta manera, la innovación de este artículo es el método de ponderación y los valores del índice de comparación por años. El índice de fortaleza de marca

a Turkish Exporters Assembly. İstanbul Commerce University. Istanbul, Turkey. Email: ulutaskubra@gmail.com 
del país (CBSI, por su sigla en inglés) se calcula para los países del G7 y Turquía utilizando el método AHP basado en encuestas, que consta de cinco indicadores diferentes que son las exportaciones, la inversión extranjera directa, el turismo, la inmigración y la gobernanza. De acuerdo con los resultados, se determina que "exportaciones" tiene el peso más importante entre esos indicadores y Canadá está en la cima obteniendo el mejor valor de índice en 2010 y 2015. Se pretende que este estudio, que se realiza con recursos limitados, arroje luz sobre las investigaciones que se realizarán en el futuro para establecer una marca de país fuerte y aumentar la competitividad del país en los mercados internacionales. En este sentido, la repetición de esta investigación en lo que respecta a las variaciones geográficas y regionales y la realización de estudios cualitativos y cuantitativos que incorporen diferentes dimensiones en el índice, como la cultura, la ciencia y la tecnología fortalecerán la literatura académica en este campo.

Palabras de clave: valor de la marca, índice de fuerza de marca de país, método AHP.

\section{Introduction}

Theories that started to be studied in the 1940's regarding the competitiveness of countries argue that factor accumulation determines competitiveness. In a global competitive environment that is heated by increasing trade wars, to get a bigger share from tourists, investors, students and entrepreneurs and to gain the interest of others, countries are competing against each other. Today, the competitiveness of countries is actualized through creating a competitive ecosystem for their companies, creating an environment that maintains prosperity for their people, and the ability to provide branding.

Starting in the late 1990's and beginning to be widely studied in the 2000's, country branding appears as an initiative that is handled by the governments of many developed and developing countries in today's world, and is shaped and implemented in line with the strategic goals of the countries. In this sense, country branding from past to present appears to be a study that has also been carefully considered by countries such as the United States and the United Kingdom in the GREAT campaign, with the production of value-added products, their export, and ultimately their branding, countries stand out by differentiating themselves from others. In this sense, Germany with its engineering and perfectionism concepts, France with its luxury and art, Italy with its design concept, the U.S. with its quality of products and services, and Turkey with its tourist attraction constitute just a few of the examples of branding in these areas.

Therefore, branding of countries gives them an advantage in a global competitive environment with the construction of an image of a confident, stable, reliable and promising country. The branding of the countries allows for increased opportunities for public diplomacy and the chance to achieve a soft power in which it highlights its cultural and social qualities, and impresses other nations. The countries that combine the soft power provided by the country branding with their hard power can show the success of being able to have an effective position in international competition.

Widely studied with the 2000's and an important concept related to country branding, country brand value has limited academic studies. Having an important role in academic literature, Fetscherin (2010) identified five dimensions of the country brand strength index as export, tourism, foreign direct investment, migration and governance, but not giving any weighting to sub dimensions. On the other hand, Anholt-GfK Nation Brand Index mentions six dimensions of the country brand index as exports, tourism, immigration / investment, governance, people and culture. In order to contribute to the current country brand index literature, sub-dimensions of the indexes are weighted with the help of the analytical hierarchy process (AHP) method. Therefore, the innovation of this paper is its weighting method and the comparison of index values by years and selected sample groups. Within this scope, the Country Brand Strength Index is calculated for eight countries and five sub dimensions using the AHP method.

\section{Literature Review}

The concept of branding in its present sense emerged in the Middle Ages. Throughout the Middle Ages, merchants in European countries had used a number of signs and symbols to identify areas where they trade, to protect their trade areas against competitors, and to differentiate their products from others. In the $17^{\text {th }}$ and $18^{\text {th }}$ centuries, factories had begun to use brands more and more to indicate quality and origin. From the $19^{\text {th }}$ century onwards, along with the developments on a global scale, the concept of branding has started to have wide coverage in the literature.

Studies on measuring the value of brands began to gain importance in the 1980's. According to Ercan et al. (2010), The first study on the determination of brand value started in England when a firm named "Rank Havis 
McDougall” asked Inter-brand, a consulting firm, to determine its brand value in order to resist the attempts of Goodman Fielder Wattie Company, one of the important companies of the food sector in England, from taking it over in 1988. After the importance of brand value was perceived by the top management of companies, multinational companies such as Canada-Dry and Colgate-Palmolive have started to include brand value managers in their organizational structures.

The increasing need for brand valuation has contributed to the increase in the number of firms providing consultancy services on this issue, with many academics and experts coming up with and applying different methods, along with an increase in the number of theoreticians and practitioners in this field. The concept of country branding was first introduced in 1996 by British researcher Simon Anholt. Alongside Simon Anholt, Wally Olins (2002), one of the first researchers who carried out studies on country brands, stated that country brands are not just concepts unique to the $21^{\text {st }}$ century, but their origins are shaped by a historical heritage dating back centuries.

According to Rojas-Méndez (2013), country branding represents a molecule of economic, political, scientific, technological, social, cultural, geographic and tourism-oriented components. Clifton (2014) claims that the countries competing to attract the world's interest and wealth can offer the opportunity to increase competitiveness with active and conscious branding, and to re-divide the world's wealth more fairly in the future when this power reaches the top in all countries. According to İlgüner (2015), a strong country brand enables the differentiation of the country's output, thus achieving a competitive advantage. A strong country brand supported by sub-brands increases national income and makes it easier for companies to enter other countries' markets. According to Nas (2017), country branding is a deep and multi-layered process in which the promotion of the country must be addressed on a level that includes not only the tourism focus, but also the entire economic, political, social, historical and cultural processes; and the need to calculate and manage the image of the country with country branding also arises.

One of the important concepts related to country branding, which started to be studied at the end of the 1990's and the beginning of the 2000's, is country brand value. Country brands, like other brand types, have a certain brand value. Country brands are a type of brand that is positioned as a result of an analysis carried out in line with the target market and competitive environment, for which a country brand identity is created within the framework of its national characteristics for the image that is desired to be achieved internationally, and which interacts with segments that may be referred to as consumers at the end of these processes. There is a limited number of research and indices on the measurement of country brand value in our country and globally.

Limited academic studies exist in order to measure country or nation brands. As seen in Table 1, the two most high-profile existing measures which assess a country brand both come from private sources rather than the academic literature: the nation brand impact framework from Brand Finance consultancy and the Anholt-GfK nation brand index (NBI).

Anholt-GfK NBI has measured the image of 50 nations annually since 2008. This annual study is conducted by GfK in partnership with Simon Anholt. Mr. Anholt developed the Nation Brands Index in 2005 as a way to measure the image and reputation of the world's nations, and to track their profiles as they rise or fall. In 2008, Simon Anholt entered a partnership with GfK.

Anholt-GfK NBI survey has been conducted in 20 major developed and developing countries that play important roles in international relations, trade and the flow of business, cultural and tourism activities. The core 20 panel countries are from Western Europe/North America, Central and Eastern Europe, Asia-Pacific, Latin

Table 1. Comparison of Country Branding Measurement and Dimensions

\begin{tabular}{llll}
\hline $\begin{array}{c}\text { Four Dimensions of the Brand } \\
\text { Finance Nation Brand Impact } \\
\text { Framework (NBIF) }\end{array}$ & \multicolumn{1}{c}{$\begin{array}{c}\text { Five Dimensions of Fetscherin's } \\
\text { Country Brand Strength Index } \\
\text { (CBSI) }\end{array}$} & $\begin{array}{c}\text { Six Dimensions of Anholt-GfK } \\
\text { Nation Brand Hexagon/Index } \\
\text { (NBI) }\end{array}$ & $\begin{array}{c}\text { Seven Dimensions of Rojas- } \\
\text { Méndez's Nation Brand Molecule } \\
\text { (NBM) }\end{array}$ \\
\hline Product & Export & Exports & Economy \\
Tourism & Tourism & Tourism & Tourism \\
Investment & Foreign Direct Investment & Immigration / Investment & Geography and Nature \\
Talent & Immigration & Governance & Government \\
- & Governance & People & Society \\
- & - & Culture & Culture and heritage \\
- & - & & Science and Technology \\
\hline
\end{tabular}

Source: The Anholt-GfK Roper Nation Brands Index (2017), Brand Finance, Fetscherin (2010), Rojas-Méndez (2013) and own compiling. 
America, Middle East/Africa. In each country, at least 1,000 adults who are internet users are interviewed. The six dimensions of Anholt-GfK Nation Brand Index are exports, tourism, immigration / investment, governance, people and culture. Each of the six indices is an average of the scores of the ratings questions from the corresponding area. There are between 3 and 5 ratings questions for each of the indices.

The Nation Brand Impact Framework used by Brand Finance has measured the strength of 147 nations since 2012. The Nation Brand Impact Framework segments the underlying factors of brand strength including investment, tourism, product and talent. Brand Finance calculates the strength of 142 nation brands by using a 'balanced scorecard approach'.

The strength of each nation brand is expressed as an indexed score out of 100 and represents how well the nation brand is being implemented against its peers. This information is then analysed using brand valuation tools that were adapted from valuation models used for corporate sector brands and intellectual property. This model incorporates, not only the strength of individual brand components, but also the general impact and size of a nation's output, trends in the nation's GDP growth, its overall development, and its development within specific segments. Although these indexes are useful and widely used for many country brand projects worldwide, they are also limited by their use of proprietary methodologies in terms of specific questions asked as well as aggregation and statistical methods used. Moreover, they are based on subjective perception survey data.

On the other hand, Rojas-Méndez (2013) uses the metaphorical approach of country brand molecule to uncover the dimensions and facets, and their intricate relationships in the context of a nation brand in general. Rojas-Méndez (2013) uses the metaphorical approach of a molecule to uncover the dimensions and facets, and their intricate relationships in the context of a nation brand in general. Results of this study have demonstrated that a nation's brand, to a large extent, is shaped by its economy, geography and nature, tourism, culture and heritage, society, science and technology, and government. As seen in Table 2, these seven main dimensions and 27 criteria match with some of those used by practitioner-led sources in order to measure a country brand.

In fact, Rojas-Méndez's results share five dimensions with the Anholt's hexagon: tourism, government, culture, society, and economy. Anholt uses separate dimensions for exports, and investment and immigration, while in this study both are classified under the economy dimension. This study ascertains two dimensions of the NBI that are not considered by either of the practitioner-led sources: geography and nature, and science and technology.

Fetscherin (2010) proposes an alternative measurement based on objective secondary data in order to assess the strength of a country brand. The construction of the country brand strength index is inspired by previous studies (Anholt, 1998; Cho \& Shu, 2006; Shimp et al., 1993) and specifically the theoretical considerations. Because country branding is unusually complex, Fetscherin does not claim that the index accounts for all dimensions of country branding. As seen in Table 3, Fetscherin presents an alternative measurement with a transparent approach and methodology based on objective secondary data.

Fetscherin (2010) uses a company-based brand equity approach applied to a country's brand by estimating how well the country performs in terms of exports (Kotler \& Gertner, 2002), attracting tourism (Caldwell \& Freire,

Table 2. Rojas-Méndez's Country Brand Molecule in 7 Dimensions and 27 Criteria

\begin{tabular}{cccccc}
\hline Economy & Tourism & $\begin{array}{c}\text { Geography } \\
\text { \& Nature }\end{array}$ & $\begin{array}{c}\text { Culture \& } \\
\text { Heritage }\end{array}$ & Society & $\begin{array}{c}\text { Science \& } \\
\text { Technology }\end{array}$ \\
\hline $\begin{array}{c}\text { Exports \& } \\
\text { Imports }\end{array}$ & $\begin{array}{c}\text { Cities \& } \\
\text { Locations }\end{array}$ & Climate & $\begin{array}{c}\text { National } \\
\text { Culture }\end{array}$ & Population & $\begin{array}{c}\text { Modernization } \\
\text { Political } \\
\text { Affairs }\end{array}$ \\
\hline $\begin{array}{c}\text { Direct } \\
\text { Foreign } \\
\begin{array}{c}\text { Investment } \\
\text { Migration }\end{array}\end{array}$ & $\begin{array}{c}\text { Recreational } \\
\text { Areas }\end{array}$ & Geo-morphology & Gastronomy & $\begin{array}{c}\text { Languages } \\
\text { \& Dialects }\end{array}$ & $\begin{array}{c}\text { Technological } \\
\text { Development }\end{array}$ \\
\hline $\begin{array}{c}\text { Economic } \\
\text { Development }\end{array}$ & Attractions & $\begin{array}{c}\text { Geographic } \\
\text { Location }\end{array}$ & Sports & Lifestyles & Inventions \\
\hline & Disasters & Education & & Health \\
\hline & Rivers, Lakes \\
$\&$ Seas & History & & \\
\hline
\end{tabular}

Source: Rojas-Méndez (2013, p. 467) and own compiling. 
Table 3. Measurement approach comparison of Fetscherin's CBSI and Anholt-GfK NBI

\begin{tabular}{|c|c|c|}
\hline & CBSI & NBI \\
\hline Export & $\begin{array}{l}\text { Export value, million, } \\
\text { USD }\end{array}$ & $\begin{array}{l}\text { Science and technology } \\
\text { Product good-will } \\
\text { Creative place }\end{array}$ \\
\hline Tourism & $\begin{array}{l}\text { Inbound tourism, } \\
\text { million people }\end{array}$ & $\begin{array}{l}\text { Desire to visit } \\
\text { Natural beauty } \\
\text { Historic landmarks } \\
\text { Vibrant city life }\end{array}$ \\
\hline $\begin{array}{l}\text { Immigration / } \\
\text { Foreign Direct } \\
\text { Investment }\end{array}$ & $\begin{array}{l}\text { Number of immigrants } \\
\& \\
\text { FDI flow }\end{array}$ & $\begin{array}{l}\text { Desire to live there } \\
\text { High quality of life } \\
\text { Good place to get education } \\
\text { Good businesses to invest in } \\
\text { Equality in society }\end{array}$ \\
\hline Governance & $\begin{array}{l}\text { Index in function } \\
\text { of exercise of } \\
\text { Political rights, rule } \\
\text { of law, public } \\
\text { Trust, free flow of } \\
\text { information, and } \\
\text { Level of corruption }\end{array}$ & $\begin{array}{l}\text { Competent and honest } \\
\text { governance } \\
\text { Citizens' rights } \\
\text { Global security } \\
\text { Environmental record } \\
\text { Reducing world poverty }\end{array}$ \\
\hline People & - & $\begin{array}{l}\text { Welcoming people } \\
\text { Appeal as friends } \\
\text { Employability of people }\end{array}$ \\
\hline Culture/ Tourism & Inbound tourism & $\begin{array}{l}\text { Sports excellence } \\
\text { Cultural heritage } \\
\text { Contemporary culture }\end{array}$ \\
\hline
\end{tabular}

Source: the Anholt-GfK Roper Nation Brands Index (2017), Fetscherin (2010) and own compiling.

2004; Hall, 2002; Morgan et al., 2002), and attracting FDIs (Papadopoulos \& Heslop, 2002; Szondi, 2008; Wee et al., 1993) as well as immigration. For those reasons, he uses the company-based brand equity approach using secondary data.

Fetscherin (2010) argues that the more exports (E), tourism (T), FDI (F), and immigration (M) a country has, along with a positive government environment $(\mathrm{G})$, the stronger the country brand. Therefore, he uses these indicators as proxies for assessing the strengths of a country brand. Assuming that to have $\mathrm{n}$ countries, the total exports of a country $i$ to all other countries $j$ where $j=1 . . . n$, can be expressed as $\mathrm{E}_{\mathrm{i}}=\sum_{j}^{n}=1 e i j$. The same applies for attracting tourism, where the total tourist arrivals in country i from all other countries $\mathrm{j}$ where $\mathrm{j}=1 \ldots \mathrm{n}$, can be expressed as $\mathrm{T}_{\mathrm{i}}=\sum_{j}^{n}=1 t i j$. The same is true for attracting FDI, $\mathrm{F}_{\mathrm{i}}=\sum_{j}^{n}=1 f i j$. as well as attracting immigration, $\mathrm{M}_{\mathrm{i}}=\sum_{j}^{n}=1 m i j$. In the model it is assumed that the government is inherent to the country and not a function of bilateral relations and it can be expressed with the parameter Gi. Therefore, the following simplified equation for CBSI for country I is formulated.

$$
C B S I=f(E i+T i+F i+M i+G i)
$$

To operationalize the CBSI, two modifications have been carried out. First, exports, tourism, FDI, and immigration are divided by the population in order to get a relative value per capita. For the government environment, Fetscherin relies on the governance environment index (GEI) provided by Li \& Filer (2007) which does not need any further modification given that it is already an index. The GEI is a multidimensional construct that includes exercise of political rights, rule of law, public trust, free flow of information, and a level of corruption. If we take $\mathrm{x}$, which is the parameter for the population, we get xi for the population of country $i$, and we can write the following equation:

$$
\begin{gathered}
\text { CBSI }=\frac{E i}{X i}+\frac{T i}{X i}+\frac{F i}{X i}+\frac{M i}{X i}+G i= \\
(E x i+T x i+F x i+M x i+G i)
\end{gathered}
$$

Since the values are still in different formats (i.e. dollar amount, people), we need to standardize the values with a mean of zero and a standard deviation of one. By calculating that and adding the five values, we construct the CBSI. To compute the CBSI for a country, all five variables must have non-missing values. We do not use imputation to fill in the missing values. We thus derive the following:

$$
\begin{aligned}
\text { CBSI }= & \frac{E x i-\overline{E x i}}{\sqrt{\sum_{i=1}^{n} \frac{(E x i-\overline{E x i})^{2}}{n-1}}}+\frac{T x i-\overline{T x i}}{\sqrt{\sum_{i=1}^{n} \frac{(T x i-\overline{T x i})^{2}}{n-1}}}+ \\
& \frac{F x i-\overline{F x i}}{\sqrt{\sum_{i=1}^{n} \frac{(F x i-\overline{F x i})^{2}}{n-1}}}+\frac{M x i-\overline{M x i}}{\sqrt{\sum_{i=1}^{n} \frac{(M x i-\overline{M x i})^{2}}{n-1}}}+ \\
& \sqrt{\sum_{i=1}^{n} \frac{(G x i-\overline{G x i}}{n-\overline{G x i})^{2}}}
\end{aligned}
$$

For simplicity and illustrative purposes, each of the five performance indicators can be expressed as $c_{k}$ where $\mathrm{k}=1 \ldots 5$. We then derive the following generic simplified equation:

$$
\mathrm{CBSI}=\sum_{k=1}^{5} \frac{c k i-\overline{c k i}}{\sqrt{\sum_{i=1}^{n} \frac{(c k i-\overline{c k i})^{2}}{(n-1)}}}
$$

Composite indexes aggregate sets of variables to condense large amounts of information in a meaningful way. Aggregation is always a potential area of methodological controversy in the field of composite index construction. 
Various aggregation (e.g. additive, multiplicative) and weighting (e.g. equal, regression) methods exist and the choice of an appropriate method depends on the purpose of the composite indicator as well as the nature of the subject being measured. Making an appropriate choice about the components of composite indexes and their weights is an important part of the aggregation process. To start, we have chosen an additive rather than a multiplicative approach since any negative or zero value might bias the results.

We have also given each component the same weight in the index since we are the first to develop such a standardized index to measure the strength of a country brand. It makes sense to begin with a simplified version of the model that can be further refined in the future.

\section{Research Methods}

In this paper, the five-dimensional structure including export, foreign direct investment, tourism, migration and ease of doing business for G7 countries and Turkey was examined as seen in Table 3.

In order to contribute to the literature by eliminating the deficiency pointed out by Fetscherin (2010), the weights of the sub-variables in the index were calculated using the survey-based Analytical Hierarchy Process (AHP) method.

Table 4. Five Sub-Variables Involved in Composite Index Calculation

\begin{tabular}{cclc}
\hline Variable & Abbreviation & \multicolumn{1}{c}{ Description } & Source \\
\hline Exporting & EXG & $\begin{array}{l}\text { Countries' exportation } \\
\text { of goods to selected } \\
\text { countries }\end{array}$ & Trademap \\
$\begin{array}{c}\text { Direct } \\
\text { Foreign } \\
\text { Investment }\end{array}$ & FDI & $\begin{array}{l}\text { Foreign direct } \\
\text { investment flow to } \\
\text { the country from the } \\
\text { selected countries }\end{array}$ & OECD \\
Governance & DOI & $\begin{array}{l}\text { World Bank Ease of } \\
\text { Doing Business Index }\end{array}$ & $\begin{array}{c}\text { World Bank } \\
\text { Doing Business }\end{array}$ \\
Number of & INBT & $\begin{array}{l}\text { Number of tourists to } \\
\text { the country from the } \\
\text { selected countries }\end{array}$ & $\begin{array}{c}\text { UNWTO, } \\
\text { Eurostat, } \\
\text { OECD }\end{array}$ \\
Immigration & MIG & $\begin{array}{l}\text { Number of migrants } \\
\text { received from the } \\
\text { selected countries }\end{array}$ & UN, OECD \\
\hline
\end{tabular}

Source: Fetscherin (2010) and our own assembly.

In this context, weights were calculated by using the SPSS-21 program, which is a statistical analysis program. For AHP analysis, which is another method for determining weights, Expert Choice 11 package program was used. G7 countries consisting partially of the United States, Japan and Canada, and the United Kingdom, Italy,
France and Germany, which is one of the first founding countries of the EU and with which Turkey has a very close commercial and social relationship and geographical proximity, were selected as samples within the scope of the research.

The share of G7 countries in Turkey's total exports was 32.2 percent as of 2018. Canada, Japan and the United States, which are less geographically and commercially close, share 6 percent of Turkey's total exports, while Germany, United Kingdom, Italy and France's share 26 percent. Therefore, the G7 countries were included in the study along with Turkey.

The calculation of weights was done separately for the years 2010 and 2015. Uninterrupted data of the 5 sub-variables that make up the index for the years 2010 and most recently 2015 are available for selected countries. In this context, representing the aftermath of the 2008 global crisis, index values were calculated and compared between periods for two different years, 2010 and more currently 2015.

The most current set of intersections of bilateral data, such as different countries exports to each other, the flow of foreign direct investment to each other, along with the number of tourists and migrants arriving to countries from other countries, is available for 2015. In this context, the constraint of the research is that there is no current data for all the variables per year.

On the other hand, different dimensions such as culture, science and technology, geography and nature, as well as language and health in the country brand molecule are not included in the index. These factors constitute the two constraints in the study.

A normalization process was performed in order to smooth the data and get more accurate results. First, variables were standardized; then, they underwent the reliability analysis. The values obtained from the reliability analysis were found to be highly reliable. Which of the five variables, consisting of exports, foreign direct investment, tourism, migration and ease of doing business, and which form of brand strength index have the most significant weight within the scope of the research was determined.

According to the index values generated by the weights determined, countries with high index value are expected to have high brand strength index value. In this context, according to the AHP method, variables with the most significant weight in dimensions were determined for 2010 and 2015. The reasons of the changes experienced in years and countries have been examined.

Statistical information about G7 countries and Turkey within the scope of the research was compiled from various sources. For export data from countries to selected 
other countries, information was taken from Trademap's bilateral trade data. For the flow of foreign direct investment from selected countries to the country, the OECD database was used; for the number of tourists, the UNWTO, Eurostat and OECD databases were used; and for the number of migrants received from selected countries, the UN and OECD databases were used. And for governance, the World Bank's Ease of Doing Business index values were used.

2010 data was also used in order to show the change between the years. Given that the number of tourists from Turkey to Canada, the number of tourists from Canada and Japan to Germany, the number of tourists from Canada to Italy, the number of tourists from Turkey to Japan, and the number of tourists from Turkey to the UK in 2010 were not available, statistics for 2011 and 2012 were used. In addition, since there are no 2010 data on the number of French refugees migrating to Germany and the most current available data was of 2008, 2008 data is used in the index calculation.

In relation to Turkey's foreign direct investment flow to Japan in 2010, figures for "Direct Investments of Domestic Residents Abroad" included in the Balance of Payments Statistics of the Central Bank of the Republic of Turkey were studied. However, this figure representing the flow amounts of direct investments made by Turkish entrepreneurs abroad was found to be zero. The fact that the figure appears as zero here does not mean that there has been no investment at all; it is estimated that a rounding has been done. For example, if a very small amount of direct investment went from Turkey that year, this figure appears to be zero.

Therefore, the fact that direct investment is zero does not mean that there was no investment at all. For example, when a Turkish entrepreneur opens a large store in Japan, but makes this investment using credit rather than his own capital, he does not enter directly into the investment item, and therefore does not appear in the statistics as there is no capital transfer.

In this sense, although it seems that no investment was made in Japan in 2010, Turkey has investments of $\$ 4$ and \$1 million respectively in 2016 and 2017. But as mentioned in the study's limitations, due to the lack of up-to-date data for each year of all variables, 2017 data was not used; therefore, the flow of foreign direct capital from Turkey to Japan in 2010 appears to be zero.

\section{AHP Method}

Developed by Thomas L. Saaty in 1971 as a multi-criterion decision making method, AHP is a multi-criteria measurement theory tool that derives scale values from binary comparisons and scoring. AHP method is used in many different scientific fields such as production, environmental management, agriculture, energy management, infrastructure, health, education, telecommunications, finance, defense, marketing, tourism, and mining (Özsoy \& Özsoy, 2018).

AHP allows the decision maker to apply their data, experience, insights and intuitions in an accurate and logical way for a complex problem by demonstrating the relationship between purpose, criteria and alternatives (Özdemir \& Saaty, 2006).

AHP stands out as a quantitative method that allows the decision maker to sort out the decision alternatives and decide which is the best; in turn answering the question "which one?". Thus, AHP is a process that develops a numerical score for ranking decision alternatives, depending on how well each alternative meets the decision maker's criteria (Russel \& Taylor III, 2003).

One of the quantitative methods for sorting and selecting decision alternatives by multiple criteria is the Analytical Hierarchy Process (AHP), which helps decision makers choose the best alternative that captures all their criteria. Through AHP, people's different feelings and understandings are harmonized.

The number of elements to be compared should be no more than 9 in order to increase consistency and to ensure the accuracy of the AHP measurement (Forman \& Gass, 2001). There are four stages in the selection-related decision problem with AHP: separation of the problem, creation of priorities, synthesis, and sensitivity analysis (Forman \& Selly, 2001).

In this context, the Country Brand Strength Index was calculated for $\mathrm{G} 7$ countries and Turkey by using the survey-based Analytical Hierarchy Process (AHP) method, consisting of 5 different dimensions: exports, foreign direct investment, tourism, migration, and governance.

In order to contribute to literature by eliminating the deficiency pointed out by Fetscherin (2010), prior to index calculation, the weights of the sub-variables to be included in the index were determined by the analytical hierarchy process (AHP) method, one of the multi-criteria decision-making methods.

In this context, the AHP method was used to answer the question, "Which of the five sub-variables related to the creation of the Country Brand Strength Index is the best: exports, foreign direct investment, governance, number of tourists and migration?" Also, the index value for 2010 and 2015 was calculated with the weight determined.

With the AHP method, firstly a survey form showing the superiority of the variables over each other was created, and an AHP questionnaire was sent to the people 
based in Turkey who stand out in terms of their brand competence; the results were collected between November and December of 2018.

In this context, the AHP method was used to determine which of the five sub-variables related to the creation of the Country Brand Strength Index: exports, foreign direct investment, ease of doing business, number of tourists and migration, is the best; and the AHP questionnaire was given to the experts who have competence in the field of branding in G7 countries and Turkey.

The AHP survey questionnaire were sent to the senior representatives of equivalent units of G7 countries' Chamber of Commerce, Chamber of Industry, and Export Support Office, and then, in turn, were evaluated. According to the results, the numerical score (i.e. index value) has been developed to rank the decision alternative, depending on how well each alternative meets the decision maker's criteria.

With the AHP method, a survey form showing the superiority of the variables over each other was created first, and the AHP questionnaire was sent to the residents of Turkey who came to the fore with their brand competence; the results were obtained between November and December of 2018.

Within the scope of the survey, brand experts from Turkey were asked to rank each of the following 5 variables (exports, foreign direct investment, ease of doing business, tourism and migration) from most to least important.

In this context, each of the sub-variables such as foreign direct investment, migration, ease of doing business, and tourism are placed to the left of the table respectively, and the other variables that are the basis for comparison are placed to the right of the table.

The experts who came to the fore with their competence on the brand were asked to compare the variable on the left and the variable on the right, as shown in Table 4 , in order to indicate which one was more important and the extent of this importance.

As can be seen in the example set in Table 4, when export and foreign direct investment variables were compared, a marking is expected to be made in the green section if the export variable to the left of the table is considered to be more important, and in the blue section if foreign direct investment was thought to be more important.

Secondly, the description of the degree of the variable's significance was given, and it was stated that a marking should be made on the table according to this degree. In this context, respondents were expected to mark the export variable by detecting one of the "extreme", "very strong", "strong" or "moderate" ratings compared to the foreign direct investment variable.

If two variables based on the comparison are considered to be significant in the "equivalent" degree, the "Equal" part was asked to be marked. When the sample AHP survey model created in Table 4 is interpreted, it is seen that exports are "very strongly" more important than foreign direct investment. The ease of doing business, on the other hand, is "strongly" more important than exports. Exports and the number of tourists coming to the country are "equally" important. Exports are "very strongly" more important than immigration.

In this context, after preparing the AHP questionnaire in separate tables for 5 different variables, evaluations of 5 people who are established in Turkey and who stand out with their brand competencies were taken between November and December of 2018, and weights were calculated accordingly to the results of the survey.

The average values of the answers from the people, who are residents in Turkey and experts on branding, were determined, as seen in Table 5. The most important value to note here is the inconsistency value. This value is expected to be less than 0.10 . Within the scope of the study, it is observed that this value is 0.02 . Therefore, the responses to the survey were found to be consistent. Among these responses, to represent Turkey, the response of the General Manager of the Independent Brand Valuation Consultancy Company was chosen.

These survey questions were sent to the G7 countries' units equivalent to the Chamber of Commerce, Chamber of industry, or Export Support Office, and one individual who stands out with their competence in branding has been asked to make an assessment. In this context, as can be seen in Table 6 , representatives

Table 5. AHP Survey Model Sample

\begin{tabular}{|c|c|c|c|c|c|c|c|c|c|}
\hline & $\begin{array}{c}\text { Extremely } \\
\text { Strong }\end{array}$ & $\begin{array}{l}\text { Very } \\
\text { Strong }\end{array}$ & Strong & Average & Equal & Average & Strong & $\begin{array}{l}\text { Very } \\
\text { Strong }\end{array}$ & $\begin{array}{c}\text { Extremely } \\
\text { Strong }\end{array}$ \\
\hline EXG & & $\mathrm{X}$ & & & & & & & FDI \\
\hline EXG & & & & & & & $X$ & & DOI \\
\hline EXG & & & & & $\mathrm{X}$ & & & & INBT \\
\hline EXG & $X$ & & & & & & & & MIG \\
\hline
\end{tabular}

Source: Özsoy \& Özsoy (2018) and own calculations. 
Table 6. Residents in Turkey that answered the AHP Survey

\begin{tabular}{lc}
\hline \multicolumn{1}{c}{ Title } & \multicolumn{1}{c}{ Response Date } \\
\hline $\begin{array}{l}\text { Expert Author on Brand Communication } \\
\text { Consultancy }\end{array}$ & $26^{\text {th }}$ of November, 2018 \\
$\begin{array}{l}\text { Brand researcher and consultant Company } \\
\text { Manager }\end{array}$ & $27^{\text {th }}$ of November, 2018 \\
$\begin{array}{l}\text { General Manager of world's leading independent } \\
\text { brand valuation consultancy company of Turkey }\end{array}$ & $30^{\text {th }}$ of November, 2018 \\
$\begin{array}{l}\text { Director of Corporate Communications at one of } \\
\text { Turkey's leading non-governmental organizations }\end{array}$ & $30^{\text {th }}$ of November, 2018 \\
$\begin{array}{l}\text { Turkey Director of a global company engaged in } \\
\text { market and public opinion research consultancy }\end{array}$ & $4^{\text {th }}$ of December, 2018 \\
\hline Source: Residents in Turkey and expert on brand depend on own calculations.
\end{tabular}

from ITC, TİM, TTM, TTG and TÜSİAD commercial contact points were contacted and sent a questionnaire. Evaluations of 7 people who are located abroad and come to the fore with their brand competencies were taken to represent 7 countries.

According to AHP results, the weight of the export variable is highest with 0.251 . The export variable is followed respectively by foreign direct investment with 0.245 , ease of doing business with 0.208 , number of tourists with 0.165 , and migration with 0.132 .

Country Brand Strength Index values for 2010 were calculated with weights reached by the AHP method and standardized data. The index value for 2010 was calculated with weights from the survey responses. However, AHP responses are thought to better represent 2015 as the most current year. Moreover, for 2010, it is thought that receiving responses according to the conditions of the period will lead to healthier results.

Among the index values calculated for the year 2010 using the weights from the AHP survey responses, as seen in Table 7, the highest was in Canada with 1.1. Canada is followed by England with 0.95 and Germany with 0.29 .

Table 8. 2010 Index Values via AHP Method in G7 Countries and Turkey

\begin{tabular}{lcccccc}
\hline \multicolumn{7}{c}{ Standardized Index Values Calculated with Weights Reached } \\
via AHP Analysis \\
\hline Countries & EXG & FDI & INBT & MIG & DOI & INDEX \\
\hline Canada & $\mathbf{0 . 5 4 9}$ & 0.011 & 0.261 & 0.165 & 0.124 & 1.110 \\
France & 0.008 & -0.119 & -0.073 & $\mathbf{0 . 0 6 6}$ & -0.190 & -0.309 \\
Germany & 0.127 & -0.082 & $\mathbf{0 . 2 0 1}$ & -0.107 & 0.070 & 0.209 \\
Italy & -0.034 & -0.084 & -0.102 & $\mathbf{0 . 0 9 7}$ & -0.257 & -0.381 \\
Japan & -0.159 & -0.117 & -0.209 & -0.196 & $\mathbf{0 . 0 7 0}$ & -0.611 \\
Turkey & -0.251 & -0.140 & -0.067 & $\mathbf{0 . 0 4 9}$ & -0.266 & -0.675 \\
England & -0.069 & $\mathbf{0 . 5 9 5}$ & 0.090 & 0.077 & 0.264 & 0.958 \\
U.S.A. & -0.172 & -0.065 & -0.100 & -0.150 & $\mathbf{0 . 1 8 6}$ & -0.301 \\
\hline
\end{tabular}

Source: Own calculations.
Table 7. Representatives of G7 Countries that answer the AHP Survey

\begin{tabular}{|c|c|c|c|}
\hline Country & Institution & Title & $\begin{array}{c}\text { Response } \\
\text { Date }\end{array}$ \\
\hline Canada & $\begin{array}{l}\text { Canada- Ontorio } \\
\text { Chamber of Commerce }\end{array}$ & $\begin{array}{l}\text { Director of SME } \\
\text { Programs \& Global } \\
\text { Growth Fund }\end{array}$ & 07.06.2019 \\
\hline France & Business France & Project Assistant & 26.04 .2019 \\
\hline Germany & Reutlingen IHK & $\begin{array}{l}\text { Director of } \\
\text { Reutlingen Chamber } \\
\text { of Commerce and } \\
\text { Industry }\end{array}$ & 19.06.2019 \\
\hline Italy & $\begin{array}{l}\text { The European House } \\
\text { - Ambrosetti }\end{array}$ & $\begin{array}{l}\text { Scenario } \\
\text { and Strategy } \\
\text { Implementation } \\
\text { Advisor }\end{array}$ & 09.04.2019 \\
\hline Japan & $\begin{array}{l}\text { Japan External Trade } \\
\text { Organization (JETRO) }\end{array}$ & $\begin{array}{l}\text { General Manager } \\
\text { of JETRO Istanbul }\end{array}$ & 29.05.2019 \\
\hline England & $\begin{array}{l}\text { Platon Financial \& } \\
\text { Strategic Consulting } \\
\text { Services Ltd. London, } \\
\text { UK }\end{array}$ & General Manager & 25.06.2019 \\
\hline The U.S.A. & $\begin{array}{l}\text { Bolloré USA Inc. - } \\
\text { New York }\end{array}$ & Analyst & 24.06 .2019 \\
\hline
\end{tabular}

Source: Representative and liaison offices of ITC, TIM, TTM and TÜSİAD.

The index values calculated for the year 2015 using the weights from the AHP survey responses, as seen in Table 8 , the highest was in Canada with 1.6, followed by Germany with 0.15 .

According to weights obtained from the AHP method, Country Brand Strength Index was calculated with normalized values for 2010 and 2015. For index calculation, export, tourism, foreign direct investment, migration and governance variables were used, taking the variables used in Fetscherin's (2010) study into account.

Fetscherin (2010) used the governance index value of Li \& Filer (2007) for the governance variable. However, in our study, one point that differs from Fetscherin (2010)

Table 9. 2015 Index Values via AHP Method in G7 Countries and Turkey

\begin{tabular}{lcccccc}
\hline \multicolumn{7}{c}{ Standardized Index Values Calculated with Weights Reached } \\
via AHP Analysis \\
\hline Countries & EXG & FDI & INBT & MIG & DOI & INDEX \\
\hline Canada & 0.532 & $\mathbf{0 . 6 0 6}$ & 0.141 & 0.282 & 0.134 & 1.695 \\
France & -0.008 & -0.088 & $\mathbf{0 . 2 7 0}$ & -0.017 & -0.067 & 0.091 \\
Germany & $\mathbf{0 . 1 7 8}$ & -0.088 & -0.108 & 0.099 & 0.068 & 0.150 \\
Italy & -0.023 & -0.087 & $\mathbf{0 . 1 4 8}$ & -0.014 & -0.249 & -0.225 \\
Japan & -0.168 & $\mathbf{- 0 . 0 7 1}$ & -0.196 & -0.096 & -0.078 & -0.610 \\
Turkey & -0.248 & $\mathbf{- 0 . 0 9 4}$ & -0.105 & -0.133 & -0.297 & -0.878 \\
England & -0.093 & -0.085 & $\mathbf{- 0 . 0 3 1}$ & -0.036 & 0.254 & 0.009 \\
U.S.A. & -0.171 & -0.093 & -0.117 & -0.085 & $\mathbf{0 . 2 3 5}$ & -0.231 \\
\hline
\end{tabular}

Source: Own calculations. 
index calculation was the use of the World Bank's ease of Doing Business Index for the governance variable, rather than $\mathrm{Li}$ and Filer's index value.

Fetscherin (2010) used mutual export, investment, tourism and migration statistics between selected countries in the index calculation. For example, the UK's index data is generated by imports from France, using the UK's foreign direct investment in France in 2015, and the number of tourists and migrants travelling from the UK to France.

\section{Result and Analysis}

Fetscherin (2010) calculated the Country Brand Power Index for 31 countries for 2007, without giving any weight to variables. In our study, using weights from the survey-based Analytical Hierarchy Process (AHP) method, the Country Brand Power Index in G7 countries and Turkey was calculated for 2015 .

Examining the data of the $5 \mathrm{sub}$-variables set between 2005 and 2017 that make up the Country Brand Strength Index, it was determined that uninterrupted data was available only in selected countries for the years 2010 and 2015.

The G7 countries including United Kingdom, Italy, France, and Germany, as it is one of the first founding countries of the EU and has a very close commercial and social relationship and geographical proximity to Turkey, and the U.S.A, Japan and Canada, as they are partially close, were selected as examples. Likewise, the share of G7 countries in Turkey's total exports was 32.2 percent as of 2018. Canada, Japan and the United States, which are geographically and commercially less close, had a 6 percent share in Turkey's total exports, while Germany, United Kingdom, Italy and France had a 26 percent share.

According to the described approach, a high Country Brand Strength Index points to the strong country brand, while a low Country Brand Strength Index points to the weak country brand. In this context, Fetscherin (2010) found in his study that out of 31 countries, Ireland had the highest score, and China had the lowest score. In this study, while the country with the highest brand strength index score was Canada, the country with the lowest score was Italy. While Turkey and Italy have negative values in Fetscherin (2010) Country Brand Power Index score, it is observed that these countries receive negative values in our study as well. In our study, Canada had the highest score, and Turkey had the lowest score.

As a result of the AHP method for 2010, for the US and Japan, ease of doing business; for Germany, tourism; for France, Italy and Turkey, immigration; for United
Kingdom, foreign direct investment; and for Canada, exports have had the most important weight.

As a result of the AHP method for 2015, the dimensions with the most significant weight were unchanged only for the USA and changed for seven countries. Countries whose weights changed according to analysis methods include Canada, France, Germany, Italy, Japan, Turkey and the United Kingdom.

\section{Conclusion}

Apart from global market research and brand valuation consulting companies, the limitation of academic studies in the literature on measuring country brand strength has been the motivating starting point for this research. Besides, the research carried out by the companies mentioned and the reports that are revealed as a result are not clearly shared with all their processes and methodologies.

Fetscherin (2010) calculated the Country Brand Strength Index values of 31 countries for 2007. However, Fetscherin (2010) did not give any weight to the 5 sub-variables that make up the brand power index. Whereas in this study, the structure consisting of 5 different dimensions including export, foreign direct investment, inbound tourism, migration and ease of doing business was examined for the G7 countries and Turkey.

In the scope of the study, the weights of the sub-variables, which constitute the brand power index through the survey-based Analytical Hierarchy Process (AHP) method were calculated. Thus, an important contribution has been made to the literature in order to eliminate the deficiencies that Fetscherin pointed out in his work.

To make these calculations in the AHP method, qualified experts in the G7 countries' units equivalent to Chamber of Commerce, Chamber of industry or Export Support Office were sent the AHP questionnaire, and asked to make assessments. Thereby, actual data and opinions of international market professionals were compared and interpreted. Important findings were made as a result of the study.

According to the AHP method, it has been determined that exports had the most significant weight within these dimensions, and Canada was ranked first in the index calculated for both years. The size with the most significant weight has remained unchanged for both years only in the United States.

In all the remaining 7 countries, the weights were also observed to change when the analyses were compared over the years.

For the United Kingdom's Brand Strength Index, tourism has taken the weight from foreign direct investment; 
in Japan's Brand Strength Index, FDI has taken the weight from doing business; and in Germany's Brand Strength Index, export has taken the weight from tourism over the years. While migration was the most important weight for France, Italy and Turkey in 2010, tourism had the most important weight in 2015 for France and Italy, but not for Turkey. For Canada, while the export variable had the most important weight, it has been replaced by foreign direct investment.

So, in other words, exports gained the most important weight for Germany, tourism the most important weight for France, Italy and the United Kingdom, and foreign direct investment the most important weight for Canada, Japan and Turkey in 2015 via the AHP method. Therefore, according to the weights obtained from the AHP method, for Canada, Japan and Turkey, the foreign direct investment variable; for France, Italy and the UK, the tourism variable; for the US, the ease of doing business variable; and for Germany, the export variable had the most important weight.

This study, with limited data, is intended to shed light on future comprehensive studies to increase competitiveness in international markets through the construction of a strong country brand. In this sense, it is expected that the research will be repeated based on geographical and regional differences, and contributions to strengthen the academic literature in this field and the advancement of the study will be made through qualitative and quantitative research carried out by adding different dimensions such as culture, science and technology in the country brand molecule to the index.

It should not be ignored that countries' brand power and competitive identities are influenced by their culture, identity, history and natural wealth. In the twenty-first century, patriotism is not about winning wars or treating a wounded economy; it is about creating a better image, and therefore a better ecosystem for products, culture, services and ideas.

Governments are also investing more seriously in areas such as tourism, cultural relations and exports, believing them to be more beneficial than political public diplomacy. In this sense, while countries that have traditionally relied on exports for foreign income continue to work to increase their visitor numbers, countries whose economies rely on their attractiveness tend to have a broad image that includes foreign direct investment, exports and other sectors.

In the study, the steps to be taken towards building a strong country brand will be of critical importance based on the results of the Country Brand Strength Index identified for Turkey. In this sense, it is assessed that the branding of
Turkey will also contribute greatly to the branding of Turkish products.

With a strong country brand strategy that encourages direct investment from outside, that will stand for a country where foreign tourists visit and spend money, whose products and services are supported in international markets, and that attracts people with ideas and abilities; it will be inevitable that Turkey will increase its national income, add value to its products and services, and compete in foreign markets with a more competitive national identity.

As a result, especially for Turkey, we hope that the Country Brand Strength Index results will contribute to the study of a country brand that will highlight the fact that we are an important country for doing business and visiting, that will be carried out with cooperation of different authorities and the contribution of the private sector, that will help raise awareness about Turkey, that will help create new international opportunities, and that will help raise the reputation of our country.

\section{References}

Anholt, S. (1998). Nation-brands of the twenty-first century. Journal of Brand Management, 5(6), 395-406. https://doi.org/10.1057/bm.1998.30

Caldwell, D., \& Freire, J. (2004). The differences between branding a country, a region and a city: Applying the brand box model. Journal of Brand Management, 12(1) 50-61. https://doi.org/10.1057/palgrave. bm. 2540201

Cho, D. S., \& Suh, Y. G. (2006). Measuring the national image: The case of South Korea. In L. Kahle \& C. H. Kim (Eds.), Creating images and the psychology of marketing communication (pp. 105-16). Lawrence Erlbaum Associates.

Clifton, R. (2014). Markalar ve Markalaşma. Türkiye $\dot{I}_{S ̧}$ Bankası Kültür Yayınları.

Ercan, M. K., Öztürk, M., Demirgüneş, K., Başçı, E., \& ve Küçükkaplan, İ. (2010). Marka Değerinin Tespiti. IMKB Yayınları.

Fetscherin, M. (2010). The determinants and measurement of a country brand: The country brand strength index. International Marketing Review, 27(4), 466479. https://doi.org/10.1108/02651331011058617

Forman, E. H., \& Gass, S. I. (2001). The analytic hierarchy process. An Exposition, Operations Research, 49(4), 469-486. https://doi.org/10.1287/ opre.49.4.469.11231

Forman, E. H., \& Selly, M. A. (2001). Decision by objectives (How to convince others that you are right). 
World Scientific Pub. Co. Researchgate database. https://doi.org/10.1142/4281

Hall, D. (2002). Brand development, tourism and national identity: The re-imaging of former Yugoslavia. Journal of Brand Management, 9(4/5), 323-334. https:// doi.org/10.1057/palgrave.bm.2540081

İlgüner, M. (2015). Derinliğine Marka. Markating Yayınlari.

Kotler, P., \& Gertner, D. (2002). Country as brand, product, and beyond: A place marketing and brand management perspective. Journal of Brand Management, 9(4/5), 249-261. https://doi.org/10.1057/palgrave. bm. 2540076

Li, S., \& Filer, L. (2007). The effects of the governance environment on the choice of investment mode and the strategic implications. Journal of World Business, 42(1), 80-98. https://doi.org/10.1016/j. jwb.2006.11.006

Morgan, N., Pritchard, A., \& Piggott, R. (2002). New Zealand, $100 \%$ pure. The creation of a powerful niche destination brand. Journal of Brand Management, 9(4\&5), 335/354. https://doi.org/10.1057/palgrave. bm. 2540082

Nas, A. (2017). Ulus Markalama: Dünyadan Örneklerle Kuram ve Uygulama. Kriter Yayınları.

Olins, W. (2002). Branding the nation-The historic context. Journal of Brand Management, 9(4/5), 241-248. https://doi.org/10.1057/palgrave.bm.2540075

Özdemir, M. S., \& Saaty, T. L. (2006). The unknown in decision making what to do about it. European Journal of Operational Research, 174(1), 349-352. https:// doi.org/10.1016/j.ejor.2004.12.017
Özsoy, H. Ö., \& Özsoy, Ç. Y. (2018). Product design concept evaluation by using analytical hierarchy and analytical network processes (pp. 120-146). https://doi. org/10.4305/METU.JFA.2018.2.8.

Papadopoulos, N., \& Heslop, L. A. (2002). Country equity and country branding: Problems and prospects. Journal of Brand Management, 9(4/5), 294-314. https://doi.org/10.1057/palgrave.bm.2540079

Rojas-Méndez, J. I. (2013). The nation brand molecule. Journal of Product \& Brand Management, 22(7), 462472. https://doi.org/10.1108/JPBM-09-2013-0385

Russel, R. S., \& Taylor III, B. W. (2003). Operations management, 4. Bask1, Pearson Education International.

Shimp, T.A., Saeed, S., \& Madden, T.J. (1993). Countries and their products: A cognitive structure perspective. Journal of the Academy of Marketing Science, 21(4), 323-330. https://doi.org/10.1007/BF02894524

Szondi, G. (2008). Pragmatic challenges to the nation-branding concept: Country promotion and image management - The case of Hungary. In K. Dinnie (Ed.), Nation branding: Concepts, issues, practice (pp. 201-205). Butterworth Heinemann Dutton.

The Anholt-GfK Roper Nation Brands Index (2017). Methodology and Quality Control Report, Gfk Public Communications and Social Science

Wee, C.H., Lim, D., \& Tan, G. (1993). The image of countries as locations for investment. In N. Papadopoulos \& L. Heslop (Eds.), Product-country images: Impact and role in international marketing (pp. 31118). Business Press. 